650

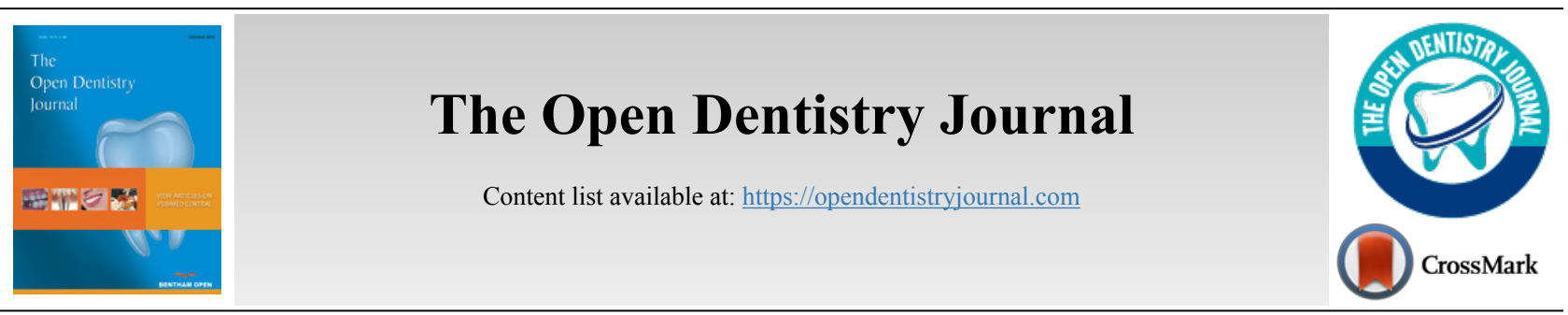

RESEARCH ARTICLE

\title{
Assessing the Students' Perception of the Quality of Dental Program offered in Saudi Arabia
}

\author{
Ahmed Al Kuwaiti, \\ ${ }^{1}$ Department of Dental Education, College of Dentistry \& Deanship of Quality and Academic Accreditation, Imam Abdulrahman Bin Faisal \\ University, Al-Khobar, Saudi Arabia
}

\begin{abstract}
:
Background:

In Saudi Arabia, dental students' program evaluation is highly focused on improving dental education quality, so that an effective workforce could be developed for the nation.

Objective:

This study aims to assess the students' perception of the quality of dental program offered at Saudi dental schools.

Methods:

All final year students of the selected Saudi dental schools $(\mathrm{N}=4)$ were included as the population of this study. The students were administered a questionnaire named "Dental Program Evaluation Survey." The survey consisted of four dimensions, with 31 Likert scale items and one global item studying the dental students' satisfaction towards the programs offered at Saudi dental schools. The responses obtained using the survey were subjected to statistical analysis using SPSS 20.0.
\end{abstract}

Results:

The results demonstrated that the dimensions, such as faculty characteristics, institutional characteristics, the efficacy of the program, and program changes due to the COVID-19 pandemic, were perceived as "High Quality." The cumulative percentage of most of the items was graded as "Acceptable." Overall, $89.2 \%$ of students were satisfied with the quality of the programs offered in their dental schools. A significant difference was found in students' perception of the dimensions and overall satisfaction with respect to their gender and dental schools.

Conclusion:

Overall, the students were highly satisfied with the quality of the dental program offered in Saudi Arabia. This study would help policymakers in developing appropriate strategies that can enhance and sustain the quality of dental program offered at Saudi dental schools.

Keywords: Dental program, Dental schools , Program evaluation survey, Satisfaction, Undergraduate dental students, Saudi dental schools.

\begin{tabular}{|l|l|l|l|}
\hline Article History & Received: June 16,2021 & Revised: October 10,2021 & Accepted: October 26, 2021 \\
\hline
\end{tabular}

\section{INTRODUCTION}

Program evaluation is termed a methodical process of changing intricacy associated with data gathering, observations, and analyses, concluding in a value decision concerning the program's quality being assessed, considered in its total, or using some of its components [1]. Program evalua-

* Address correspondence to this author at the Department of Dental Education, College of Dentistry \& Deanship of Quality and Academic Accreditation, Imam Abdulrahman Bin Faisal University, P.O. box 40065, Al-Khobar 31952, Saudi Arabia; Tel: +966 13 3332500; Fax: +966 13 3330380; Phone: +966 505843183; E-mail: akuwaiti@iau.edu.sa tion refers to applying assessment approaches, methods, and knowledge to methodically evaluate and assess the planning, execution, and efficacy of programs [2]. It provides the stakeholders with a meaning of quality for their program. Program evaluation models alone are not likely to focus on the assessment of quality implementation. Such models emphasize systematic data collection on the program and describe strengths and weaknesses to pursue decision-making [1]. The program assessment aims to provide feedback on how the program could be enhanced. It informs faculty and decisionmakers about the contribution and impact of the program. It 
informs the stakeholders regarding the achievements of the program. It offers support for program review, strategic planning, and accreditation [3]. Students' evaluation surveys on specific aspects of higher education institutions (HEIs), including programs, provide valued information, thus helping in managing higher education quality [4]. Accordingly, higher education institutions (HEIs) are actively engaged in assessing their programs' quality using students' feedback since those are the primary customers of HEIs $[5,6]$.

Though various health science programs are offered by HEIs, the dental program is treated as one of the vital programs since the dental professions play an essential role in meeting the oral health necessities and individuals' demands [7]. Generally, the dental program is offered by dental schools in various countries around the world. The dental workforce is rising as more students graduate from dental schools, and supplementary expatriate dentists are licensed in the United States [8]. As such, various dental schools in Saudi Arabia offer dental program to the student community across the globe. In Saudi Arabia, an intense rise in dental colleges' count was observed in less than a decade. Such a rise showed a substantial increase in the volume of dental graduates, and thereby demanded a rise in the job openings for the fresh dental graduates [9]. However, the COVID-19 pandemic pushed Saudi and global HEIs to close down and the students were directed to practice social distancing as the critical preventive approach [10]. Though the COVID-19 pandemic has led to several snags in delivering clinical dentistry, dental instructors are offered the chance to update their methods to proper pedagogy through recent digital ideas and improving online communication and usage of learning platforms [11].

Concerning Saudi dental schools' accreditation, National Center for Academic Accreditation and Assessment (NCAAA) is authorized to observe academic accreditation processes and grant academic accreditation for HEIs, including dental schools. Dental schools must evaluate their program from the students' perspective using surveys, thereby improving dental education quality and attaining academic accreditation. In the Saudi Arabian context, an earlier study utilized the program evaluation survey (PES) at the end of the program to assess the students' experience of the undergraduate dental program offered by a Saudi University. It has been concluded that irrespective of timing for PES, there is a need for improvement related to every question confirming continuing developmental phase [12]. It also conducted a comparative appraisal between PES and student experience survey (SES) concerning the undergraduate dental students' experience of their program. Another study by Al Rubaish [13] discussed the utility of the global items' results with the individual items in enhancing the quality of higher education. The students' experience at the end of their academic programs offered by a Saudi medical and dental school was evaluated using PES. The results demonstrated the poorly graded global items results. This finding indicates the need to emphasize global item findings and attain ongoing progress in all the areas emphasized in the survey. To warrant the findings' generalizability even in identical settings, the programs comprising more students would be a better choice. Abdelsalam et al. [14] explored the faculty and students' level of satisfaction with their dental curriculum in a Saudi dental school. A high level of satisfaction was reported by faculty than students as faculty perceived that the curriculum developed proficient graduates. Areas that required to be focused on were revealed to restructure the future curriculum in order to make good graduates with capabilities associated with the international benchmarks and Saudi Arabia Qualification Framework recommendations.

While reviewing the previous literature, two studies by Al Rubaish in 2011 [12, 13] assessed the dental students' feedback using PES, where the first one dealt with the comparative analysis of PES timings with the student experience survey (SES) and another study with the global items' usefulness. However, in the Saudi Arabian context, no exclusive studies have focused on evaluating dental program's quality from the students' perspective in recent times, considering the COVID-19 pandemic. Hence, this study intended to assess the students' perception of the quality of undergraduate dental program offered at Saudi dental schools. The findings would help policymakers of Saudi dental schools frame strategies for improving and sustaining the quality of dental program.

\section{MATERIALS AND METHODS}

\subsection{Study Population}

In this study, the exploratory study design was applied to assess the students' perception of the quality of dental program offered at Saudi dental schools. The study population involved all the final year students belonging to the undergraduate program of the selected Saudi dental schools $(\mathrm{N}=4)$ during the academic year 2020-21. The distribution of final year students $(\mathrm{N}=530)$ among the selected four Saudi dental schools viz., King Saud University (KSU), King Abdulaziz University (KAU), Imam Abdulrahman Bin Faisal University (IAU), and Al Jouf University (JU) was 180, 160, 100, and 90, respectively. The students were administered with a selfstructured questionnaire using an online application. The ethical approval for this study was obtained from the Institutional Review Board (IRB), Imam Abdulrahman Bin Faisal University (IAU), Saudi Arabia.

\subsection{Questionnaire}

This study used the "Dental Program Evaluation Survey (Dental PES)," a self-structured questionnaire, to attain its objectives. The survey is a modified version of the instrument formed by Al Rubaish [12]. It has two sections. The first section, named "I. Demographic profile," includes 06 items covering the respondents' demographic information. The second section, named "II. Factors influencing the students' perception of the Dental program quality," involves four aspects with a total of 31 items. Those aspects are faculty characteristics (07 items), institutional characteristics (09 items), the efficacy of the program (09 items), and program changes due to the covid-19 pandemic (06 items). It has a global item (one item) covering the students' overall satisfaction regarding the dental program's quality. The responses are recorded with a five-point Likert scale (Strongly agree (5), Agree (4), Neutral (3), Disagree (2), and Strongly disagree (1)). All participants were requested to complete this 
survey within a stipulated time frame after filling the informed consent form.

While testing the reliability and validity, the overall Cronbach alpha value was found as 0.885 , which demonstrated that the variables assessing the concept of the instrument could be graded as "good" [15]. Hence, it also indicated the instrument to be a reliable one. The Cronbach alpha value of the dimensions, such as faculty characteristics, institutional characteristics, the efficacy of the program, and program changes due to the COVID-19 pandemic was observed as $0.851,0.878,0.784$, and 0.860 , respectively. Furthermore, a confirmatory factor analysis (CFA) with the varimax rotation method described 62.652 percent of the variance in students' perception towards the quality of dental program offered at Saudi dental schools. Besides, a performance grading criterion used by Al Rubaish $[12,13]$ was adopted to describe the mean scores of responses recorded towards each dimension of the survey used. This criterion describes the mean scores as follows: (i) High quality (3.6 \& above), (ii) Acceptable (2.6-3.6), (iii) Improvement required (below 2.6). Also, the cumulative percentage data of students chosen for either "Agree" or "Strongly agree" on all items in the Dental PES were explained as (i) High quality ( $80 \%$ \& above), (ii) Acceptable (60-80\%), (iii) Improvement required (Less than $60 \%$ ). The data obtained were further subjected to statistical analysis using appropriate statistical tools.

\subsection{Statistical Analysis}

Dental students' perceptions regarding the dental PES dimensions were analyzed using a mean score and the cumulative percentage data chosen for both "Agree" and "Strongly agree" on the five-point Likert scale. A one-way multivariate analysis of variance (MANOVA) was applied to reveal any significant difference among the students' perception of dental PES dimensions concerning their gender and dental schools. Further analysis was carried out using the Univariate ANOVA to observe whether there was any significant difference in the students' perception among the dental schools concerning the dental PES dimensions. All statistical analyses were performed through SPSS 20.0 at the level of significance of $5 \%$.

\section{RESULTS}

Out of 445 completed surveys by the participants, 182 (41\%) were male, and 263 (59\%) female. Those respondents were Saudis. The distribution of respondents belonging to the selected dental schools, namely King Saud University (KSU), King Abdulaziz University (KAU), Imam Abdulrahman Bin Faisal University (IAU), and Al Jouf University (JU), was observed as $146(33 \%), 132(30 \%), 91(20 \%)$, and $76(17 \%)$, respectively. The response rate was assessed as $84 \%$. Further, the demographic characteristics of the respondents are described in Table 1. The results showed that the mean score of the survey dimensions, namely faculty characteristics, institutional characteristics, efficacy of the program, and program changes due to the COVID-19 pandemic, was 4.27 , $4.16,4.22$, and 4.31, respectively. Based on the adopted criteria, these dimensions were perceived as "High Quality." The range of the mean score of the items under four dimensions was observed from 3.78 to 4.46 . While analyzing the cumulative percentage results, the highest value was observed as $86.5 \%$ indicating that the students agreed that their dental college offered sufficient knowledge and insisted on good practice to combat COVID-19. As the lowest value, $62 \%$ agreed that the library resources were sufficient and available when the students needed them. A total of 10 items were observed with a cumulative percentage of more than $80 \%$ and graded as "High Quality," and the remaining items were observed as "Acceptable" (i.e., 60-80\%). The global item showed a mean score of 4.49 , and $89.2 \%$ of respondents were overall satisfied with the quality of their learning experiences at their institution's dental program, and it was graded as "High Quality" (Table 2).

Table 1. Demographic characteristics.

\begin{tabular}{|c|c|c|c|}
\hline \multirow{2}{*}{ University } & \multicolumn{2}{|c|}{ Number of Respondents } & \multirow{2}{*}{ Total } \\
\cline { 2 - 3 } & Male & Female & \\
\hline KSU & 63 & 83 & 146 \\
\hline KAU & 56 & 76 & 132 \\
\hline IAU & 35 & 56 & 91 \\
\hline Al Jouf & 28 & 48 & 76 \\
\hline \multicolumn{3}{|c|}{ Total } & 445 \\
\hline
\end{tabular}

Table 2. Mean score and the cumulative percentage of students who chose either "Agree" or "Strongly agree" on several items in the Dental PES.

\begin{tabular}{|c|c|c|c|}
\hline S.No. & Items & $\begin{array}{c}\text { Mean } \pm \text { Standard } \\
\text { Deviation }\end{array}$ & $\begin{array}{l}\text { Agreement } \\
\text { Scores (\%) }\end{array}$ \\
\hline \multicolumn{4}{|c|}{ I Faculty Characteristics $(4.27 \pm 0.74)$} \\
\hline Q7 & The instructors were available for consultation and advice when I needed to speak with them. & $4.24 \pm 0.86$ & 81.2 \\
\hline Q8 & The instructors in the dental program inspired me to do my best. & $4.29 \pm 0.84$ & 81.6 \\
\hline Q9 & The instructors in the program gave me helpful feedback on my work. & $4.46 \pm 0.77$ & 86.3 \\
\hline Q10 & The instructors in the program had a thorough knowledge of the content of their courses. & $4.23 \pm 0.88$ & 76.4 \\
\hline Q11 & The instructors were enthusiastic about the program. & $4.00 \pm 0.89$ & 68.4 \\
\hline Q12 & The instructors cared about my progress. & $4.10 \pm 0.88$ & 70.5 \\
\hline Q13 & The instructors conduct effective practical training sessions and assessments. & $4.12 \pm 0.91$ & 73.9 \\
\hline \multicolumn{4}{|c|}{ II Institutional Characteristics (4.16 \pm 0.76$)$} \\
\hline Q14 & Study materials in the courses were up-to-date and useful. & $4.39 \pm 0.81$ & 83.2 \\
\hline
\end{tabular}




\begin{tabular}{|c|c|c|c|}
\hline S.No. & Items & $\begin{array}{l}\text { Mean } \pm \text { Standard } \\
\text { Deviation }\end{array}$ & $\begin{array}{l}\text { Agreement } \\
\text { Scores (\%) }\end{array}$ \\
\hline Q15 & Library resources were adequate and available when I needed them. & $3.93 \pm 0.93$ & 62.0 \\
\hline Q16 & Classroom facilities (for lectures, labs, etc.) were of good quality. & $4.17 \pm 0.96$ & 73.9 \\
\hline Q17 & Computer facilities for students were sufficient for my needs. & $3.96 \pm 0.99$ & 66.3 \\
\hline Q18 & Adequate facilities were available for extracurricular activities (e.g., sports \& recreation). & $4.01 \pm 0.98$ & 69.4 \\
\hline Q19 & Adequate facilities were available for religious observances. & $3.94 \pm 1.16$ & 66.8 \\
\hline Q20 & $\begin{array}{l}\text { Field experience programs (internship, practical, cooperative training) were effective in developing } \\
\text { my skills (If applicable to your dental program). }\end{array}$ & $3.78 \pm 0.98$ & 65.6 \\
\hline Q21 & Adequate academic and career counseling was available for me throughout the dental program. & $4.29 \pm 1.00$ & 81.5 \\
\hline Q22 & $\begin{array}{c}\text { I am satisfied with the students' evaluation surveys conducted to improve the quality of dental } \\
\text { education. }\end{array}$ & $4.42 \pm 0.83$ & 84.4 \\
\hline \multicolumn{4}{|c|}{ III Efficacy of the Program (4.22 \pm 0.68$)$} \\
\hline Q23 & What I have learned in this dental program will be valuable for my future. & $4.14 \pm 0.83$ & 77.2 \\
\hline Q24 & $\begin{array}{l}\text { As a result of this program, I have developed sufficient interest to keep up-to-date with new } \\
\text { developments in my field of study. }\end{array}$ & $4.17 \pm 0.84$ & 77.7 \\
\hline Q25 & The program developed my ability to investigate and solve new problems. & $4.11 \pm 0.86$ & 76.2 \\
\hline Q26 & The program improved my ability to work effectively in groups. & $4.13 \pm 0.86$ & 76.2 \\
\hline Q27 & The program improved my communication skills. & $4.22 \pm 0.99$ & 75.1 \\
\hline Q28 & $\begin{array}{l}\text { I have developed good basic skills in using technology to investigate issues and communicate } \\
\text { results. }\end{array}$ & $4.39 \pm 0.82$ & 83.9 \\
\hline Q29 & I am confident that I have developed the knowledge and skills required for my chosen career. & $4.03 \pm 1.00$ & 69.8 \\
\hline Q30 & $\begin{array}{l}\text { I am satisfied with the knowledge and skills that I acquired at this dental program of my } \\
\text { institution/college. }\end{array}$ & $4.32 \pm 0.97$ & 78.5 \\
\hline Q31 & I am not stressed with the objective structured clinical examination (OSCE) assessment. & $4.06 \pm 0.93$ & 70.6 \\
\hline \multicolumn{4}{|c|}{ IV Program Changes due to COVID-19 Pandemic (4.31 \pm 0.71$)$} \\
\hline Q32 & My dental college offered adequate knowledge and insisted on good practice to combat COVID-19. & $4.44 \pm 0.79$ & 86.5 \\
\hline Q33 & My dental college provided academic services efficiently during the COVID-19 pandemic. & $4.03 \pm 0.91$ & 67.2 \\
\hline Q34 & $\begin{array}{c}\text { My dental college offered an active online learning environment (online educational platforms, e- } \\
\text { learning resources, etc.) during the COVID-19 pandemic. }\end{array}$ & $4.06 \pm 0.86$ & 69.4 \\
\hline Q35 & $\begin{array}{l}\text { The instructors motivate and support me in effective learning and research during the COVID-19 } \\
\text { pandemic. }\end{array}$ & $4.05 \pm 0.86$ & 78.6 \\
\hline Q36 & $\begin{array}{l}\text { During the COVID-19 pandemic, my dental college adopted sufficient preventive measures during } \\
\text { the practical training sessions. }\end{array}$ & $4.36 \pm 0.81$ & 83.0 \\
\hline Q37 & $\begin{array}{l}\text { I am satisfied with the measures taken by my dental college to ensure the quality of dental } \\
\text { education. }\end{array}$ & $4.39 \pm 0.85$ & 84.2 \\
\hline \multicolumn{4}{|c|}{ V Overall Satisfaction } \\
\hline Q38 & $\begin{array}{c}\text { Overall, I am satisfied with the quality of my learning experiences at this dental program of my } \\
\text { institution. }\end{array}$ & $4.49 \pm 0.72$ & 89.2 \\
\hline
\end{tabular}

Table 3. MANOVA assessing students' perception of the quality of dental program with respect to their gender and dental schools.

\begin{tabular}{|c|c|c|c|c|c|c|}
\hline \multicolumn{2}{|c|}{ Category } & Faculty Characteristics & Institutional Characteristics & Efficacy of the Program & $\begin{array}{l}\text { Program Changes Due to } \\
\text { COVID-19 Pandemic }\end{array}$ & p-value \\
\hline \multirow{2}{*}{ Gender } & Male & $3.99(0.81)$ & $4.01(0.85)$ & $4.01(0.68)$ & $4.32(0.70)$ & \multirow{2}{*}{$0.000 *$} \\
\hline & Female & $4.47(0.61)$ & $4.27(0.67)$ & $4.36(0.64)$ & $4.30(0.71)$ & \\
\hline \multirow{4}{*}{$\begin{array}{l}\text { Dental } \\
\text { Schools }\end{array}$} & KSU & $4.40(0.65)$ & $4.08(0.72)$ & $4.34(0.70)$ & $4.38(0.65)$ & \multirow{4}{*}{$0.000 *$} \\
\hline & KAU & $4.27(0.69)$ & $4.16(0.77)$ & $4.20(0.66)$ & $4.34(0.79)$ & \\
\hline & IAU & $4.23(0.80)$ & $4.31(0.78)$ & $4.19(0.59)$ & $4.26(0.70)$ & \\
\hline & Al Jouf & $4.09(0.87)$ & $4.17(0.79)$ & $4.07(0.74)$ & $4.19(0.67)$ & \\
\hline
\end{tabular}

*Significant at 0.05 level. 
Table 4. ANOVA assessing students' perception of the four dental PES dimensions with respect to their dental schools.

\begin{tabular}{|c|c|c|c|c|}
\hline Source of Variance & Dependent Variables & Sum of Squares & Mean Square & p-value \\
\hline \multirow{4}{*}{ Dental schools } & Faculty characteristics & 4.911 & 1.637 & $0.029 *$ \\
\hline & Institutional characteristics & 3.033 & 1.011 & 0.155 \\
\hline & Efficacy of the Program & 3.927 & 1.309 & $0.035^{*}$ \\
\hline & Program changes due to the COVID-19 pandemic & 2.322 & 0.774 & 0.198 \\
\hline
\end{tabular}

*Significant at 0.05 level.

Table 5. Independent ' $t$ ' test for students' overall satisfaction of the quality of learning experience in the dental program with respect to their gender.

\begin{tabular}{|c|c|c|c|c|}
\hline Dependent Variable & Gender & $\mathbf{N}$ & $\begin{array}{c}\text { Mean } \pm \\
\text { Standard Deviation }\end{array}$ & p-value \\
\hline $\begin{array}{c}\text { Students' overall } \\
\text { satisfaction }\end{array}$ & Male & 182 & $4.43 \pm 0.803$ & \multirow{2}{*}{$0.006^{*}$} \\
\cline { 2 - 4 } & Female & 263 & $4.54 \pm 0.658$ & \\
\hline
\end{tabular} *Significant at 0.05 level.

Table 6. ANOVA assessing students' overall satisfaction of the quality of learning experience in the dental program with respect to their dental schools.

\begin{tabular}{|c|c|c|c|c|c|c|}
\hline $\begin{array}{c}\text { Dependent } \\
\text { Variable }\end{array}$ & \multicolumn{2}{|c|}{$\begin{array}{l}\text { Source of } \\
\text { Variance }\end{array}$} & $\begin{array}{c}\text { Mean } \\
\pm \text { Standard } \\
\text { Deviation }\end{array}$ & $\begin{array}{l}\text { Sum of } \\
\text { Squares }\end{array}$ & \begin{tabular}{|l} 
Mean \\
Square
\end{tabular} & p-value \\
\hline \multirow{4}{*}{$\begin{array}{c}\text { Students' } \\
\text { Overall } \\
\text { Satisfaction }\end{array}$} & \multirow{4}{*}{$\begin{array}{l}\text { Dental } \\
\text { School }\end{array}$} & KSU & $4.65 \pm 0.606$ & \multirow{4}{*}{8.388} & \multirow{4}{*}{2.796} & \multirow{4}{*}{$0.001 *$} \\
\hline & & KAU & $4.52 \pm 0.671$ & & & \\
\hline & & \begin{tabular}{|l|} 
IAU \\
\end{tabular} & $4.41 \pm 0.816$ & & & \\
\hline & & \begin{tabular}{|c|} 
Al \\
Jouf
\end{tabular} & $4.26 \pm 0.822$ & & & \\
\hline
\end{tabular}

Further, MANOVA showed a significant difference in the students' perception of the quality of their dental program with respect to their gender and dental schools $(\mathrm{p}<0.05)$ (Table 3 ). While reviewing the mean agreement score of students as regards to gender, females showed a higher mean score than males in all dimensions except for program changes due to the COVID-19 pandemic (Table 3). Besides, the students' perception of each dimension of the Dental PES concerning their dental schools was revealed using ANOVA (Table 4). The results showed a significant difference in the dental students' perception over the two dimensions, namely faculty characteristics and efficacy of the program. However, the remaining dimensions failed to show a significant difference. Subsequently, a Tukey's HSD post-hoc test was performed with the significant dimensions observed in ANOVA concerning the dental schools. While observing the students' perception of faculty characteristics, a significant mean difference was found between KSU and Al Jouf $(\mathrm{p}<0.05)$. Based on the mean score, it is revealed that the dental students of KSU were more satisfied with faculty characteristics than those of KAU, IAU, and Al Jouf. Further, a significant mean difference was observed between KSU and Al Jouf $(p<0.05)$ concerning the efficacy of the program. Based on the mean score, it has been observed that the dental students of KSU were more satisfied with the efficacy of the program than those of KAU, IAU, and AlJouf.

Regarding the dental students' overall satisfaction, the independent ' $t$ ' test revealed a significant gender difference in the students' overall satisfaction. Overall, female students (mean=4.54) were more satisfied than male students (mean=4.43) concerning the quality of the learning experience with the dental program offered at their dental schools $(\mathrm{p}<0.05)$ (Table 5). Besides, the overall satisfaction of the students' belonging to the selected Saudi dental schools was observed as 4.65 (KSU), 4.52 (KAU), 4.41 (IAU), and 4.26 (Al Jouf), respectively. There was a significant difference observed in the students' overall satisfaction with respect to their dental schools $(\mathrm{p}<0.05) \quad($ Table 6). Notably, a significant mean difference was found only between KSU and Al Jouf using Tukey's HSD post-hoc test.

\section{DISCUSSION}

In this study, the dental students perceived the dimensions, such as faculty characteristics, institutional characteristics, the efficacy of the program, and program changes due to the COVID-19 pandemic as positive with a mean score of greater than 4.0. Overall, the students' perception of the quality of learning experience in the dental program offered at their dental schools was observed as 4.49. Using the adopted performance grading criteria, those dimensions and students' overall satisfaction were sorted as "High Quality", since their mean scores were equal to or greater than 3.6 using a Likert scale. Contrary to these findings, Al Rubaish [13] observed that a Saudi university's dental students rated most items and a global item of PES with the mean score graded as "Acceptable." However, in this study, the cumulative percentage of 21 items under four dimensions was observed between $60-80 \%$, i.e., Acceptable. It denotes a scope for further improvement, and the policymakers should focus on those items employing the appropriate strategies in order to enhance the quality of dental program offered in Saudi Arabia.

Further, the results indicated a significant difference in the students' perception of dental PES dimensions with respect to their gender and dental schools. Based on the mean score, it has been observed that females were more satisfied than males concerning all dimensions except for program changes due to the COVID-19 pandemic. As the students were observed under the umbrella of public dental schools in Saudi Arabia and were experiencing uniform regulations, this observation might be due to the gender-specific variation in their perception according to their needs and expectations towards the dimensions, such as faculty characteristics, institutional characteristics, the efficacy of the program, and program changes due to the COVID-19 pandemic. In line with this result, Lavin et al. [16] noted that females rated the instructor's characteristics statistically higher than males, such as professionalism, clear presentations, concise explanations, 
enthusiasm, responsiveness, and encouragement. Jawaid et al. [17] stated that female students observed their academic environment to be more positive than their male counterparts. Daniel et al. [18] observed that female students were highly satisfied with the university's facility provision than male students. Besides, a study by Binshehab and Ingle [19] in Saudi Arabia found the undergraduate dental students' perception regarding online learning to be positive. Aziz Ansari et al. [20] have also observed that $62 \%$ of the students expressed their satisfaction with online learning in Saudi universities during the COVID-19 pandemic.

Besides, this study revealed the students' perception of each dimension of dental PES concerning their dental schools. Concerning the faculty characteristics, a significant difference was observed in students' perception of the selected dental schools. This difference might be due to each faculty member's unique qualities and attributes though the faculty member belonging to public dental schools. A study by Riedy et al. [21] revealed a significant difference in students' perceptions of the instructor attributes. Al-Jobair and AlSarheed [22] observed that Saudi dental students perceived their faculty's performance characteristics as highly vital for their effective learning compared to personality attributes. Cultural and instructive factors play a key role in altering students' perception of the active teacher's qualities.

Regarding the efficacy of the dental program, a significant difference was observed in the perception of the students belonging to the selected dental schools. Though the public dental schools have uniform curriculum content and course delivery, this finding may be due to the variation in the students' perceived self-efficacy and self-confidence obtained through the dental program. Further, undergraduate dental programs are based on a list of competencies to be achieved by the student in order to be able to function professionally in a dental practice after graduation from the dental school [23]. Students' self-efficacy is sensitive to changes in teaching strategies and plays a spontaneous role in academic skills growth and usage [24]. A recent study by Baaij et al. [25] observed that the self-efficacy of students from Aarhus University did not differ significantly from that of students enrolled in the standard program at the Academic Center for Dentistry at Amsterdam. Besides, Akhlaghi et al. [26] observed that various teaching methods and learning processes influence the students' self-perceived confidence.

Next, the dimension "institutional characteristics" demonstrated no significant difference in the students' perception concerning their dental schools. This finding might be because the public dental schools run by the Ministry of Education (MOE) of Saudi Arabia are governed by uniform regulations regarding the institutional facilities and learning environment. Subsequently, there was no significant difference found in students' perception towards the program changes due to the COVID-19 pandemic with reference to their dental schools. This result might be because the MOE has laid the uniform rules for Saudi universities to execute the teaching and learning processes and conduct academic services effectively during the COVID-19 pandemic. During the COVID-19 pandemic, the Saudi MOE declared that the learning process has to be continued through online classes in a harmless and protected manner. Subsequently, all universities comprising medical disciplines shifted to online learning [27]. Alzahrani et al. [11] stated that the COVID-19 pandemic has created clinical dentistry and dental education challenging. However, the dental instructors have the abilities and tools to update their teaching methods through adopting current digital concepts augmenting online communication.

Finally, there was a significant difference observed in the students' overall satisfaction as regards their gender and dental schools. Overall, females were more satisfied than males concerning the quality of the learning experience at their dental schools' program $(p<0.05)$. This finding may be due to the gender-specific variation in the students' overall satisfaction. In accord with this finding, Sabbagh et al. [28] observed that female students obtained a slightly higher mean Dundee ready educational environment measure (DREEM) score than male students in a Saudi dental school. In contrast, Al-Samadani et al. [29] found no significant gender difference in the mean domain values and total DREEM values among Saudi dental school students.

\subsection{Strategies suggested for improving the Quality of Dental programs offered in Saudi Arabia}

As the students are identified as key consumers and endusers of higher education, their views and satisfaction are imperative in enhancing its quality [30]. Hence, based on the students' feedback, higher administrators should frame appropriate strategies to improve the quality of the dental program. As such, this study recommends the following strategies to improve the quality of dental education programs offered in Saudi Arabia:

(1) During the new normal situation, dental schools have gradually shifted from blended learning (i.e., with $25-75 \%$ online learning) to $100 \%$ online learning. As a result, they should train their students to actively use information and communication technology (i.e., Zoom, Microsoft teams, Blackboard learning management system, and online survey tools).

(2) Teachers must be trained to utilize modern technologybased teaching devices to deliver their lectures online, in both blended and hybrid modes.

(3) The instructors should keep an eye on the students' progress and conduct safe and effective practical training sessions and assessments with sufficient preventive measures considering the adverse effects of COVID-19.

(4) Dental schools should maintain adequate and readily available learning resources to aid students during online and blended learning processes.

(5) The students should be equipped with enough knowledge and skills to perform research in a safe clinical environment. It is recommended to develop collaborative training and mentoring programs for both faculty and students.

(6) It is mandatory to conduct various online surveys periodically to collect the students' feedback about online learning, blended learning, learning resources, teaching quality, 
research, attained competencies, facilities, and program learning outcomes. The surveys need to be redesigned with an emphasis on the COVID-19 pandemic and online education.

(7) The schools should develop communication skills and encourage teamwork among the students to aid them in their future careers.

\section{CONCLUSION}

Overall, the students were observed to be highly satisfied with the quality of the dental program offered in their Saudi dental schools. This study revealed that the dimensions, such as faculty characteristics, institutional characteristics, the efficacy of the program, and program changes due to the COVID-19 pandemic, were perceived as "High Quality" by the Saudi dental students. A significant difference was also noted in the students' perception towards all the dimensions and students' overall satisfaction concerning their gender and dental schools. Further, a significant difference was observed in the perception of students of the selected Saudi dental schools with respect to the faculty characteristics and efficacy of the program. The present study recommends that Saudi dental schools develop suitable strategies which may help enhance the students' satisfaction over the quality of the program being offered.

\section{LIMITATIONS AND RECOMMENDATIONS}

This study is only limited to assessing the students' perception of the quality of undergraduate dental program offered at public dental schools in Saudi Arabia. It observed a significant difference in the students' perception of dental PES dimensions concerning their gender and dental schools. However, the relationship between dental PES dimensions and students' overall satisfaction could be further revealed. Also, the factors influencing the students' overall satisfaction towards the quality of dental program have been explored. Moreover, future research can be conducted including the students of private dental schools of Saudi Arabia so that a comparison can be made of their perception of the quality of the dental program with the perception of students in public dental schools.

\section{ETHICS APPROVAL AND CONSENT TO PARTI- CIPATE}

The ethical approval for this study was obtained from the Institutional Review Board (IRB), Imam Abdulrahman Bin Faisal University (IAU), Saudi Arabia.

\section{HUMAN AND ANIMAL RIGHTS}

No animals were used in this research. All human research procedures were followed in accordance with the ethical standards of the committee responsible for human experimentation (institutional and national), and with the Helsinki Declaration of 1975, as revised in 2013.

\section{CONSENT FOR PUBLICATION}

Informed consent has been obtained from the participants.

\section{AVAILABILITY OF DATA AND MATERIALS}

The data that support the findings of this study are available on reasonable request from the corresponding author. The data are not publicly available due to information that could compromise the privacy of research participants.

\section{FUNDING}

None.

\section{CONFLICT OF INTEREST}

The authors declare no conflict of interest, financial or otherwise.

\section{ACKNOWLEDGEMENTS}

Declared none.

\section{REFERENCES}

[1] Mizikaci F. A systems approach to program evaluation model for quality in higher education. Qual Assur Educ 2006; 14(1): 37-53. [http://dx.doi.org/10.1108/09684880610643601]

[2] Smith PS. From scarcity to abundance: it's role in achieving qualityassured mass higher education. J Asynchronous Learn Netw 2011; 15(2): 6-21.

[http://dx.doi.org/10.24059/olj.v15i2.181]

[3] University of Central Florida (UCF). Program assessment handbook: guidelines for planning and implementing quality enhancing efforts of program and student learning outcomes. 2008. Available from: https://oeas.ucf.edu/doc/acad_assess_handbook.pdf

[4] Al Rubaish A. On the contribution of student experience survey regarding quality management in higher education: An institutional study in Saudi Arabia. J Serv Sci Manag 2010; 3(4): 464-9.

[http://dx.doi.org/10.4236/jssm.2010.34052]

[5] Abdullah F. Measuring service quality in higher education: HEdPERF versus SERVPERF. Mark Intell Plann 2006; 24(1): 31-47.

[http://dx.doi.org/10.1108/02634500610641543]

[6] Soedijati EK, Pratminingsih SA. The impacts of marketing mix on students choice of university study case of private university in Bandung, Indonesia. 2nd International conference on business and economic research proceeding (ICBER 2011). 2124-31.

[7] Gallagher JE, Manickam S, Wilson NH. Sultanate of Oman: Building a dental workforce. Hum Resour Health 2015; 13(50) [http://dx.doi.org/10.1186/s12960-015-0037-z]

[8] Diringer J, Phipps K, Carsel B. Critical trends affecting the future of Dentistry: assessing the shifting landscape. American Dental Association 2013. Available from: http://www.ada.org/ /media/ADA/Member\%20Center/FIles/Escan201 3_Diringer_Full.ashx

[9] AlBaker AA, Al-Ruthia YSH, AlShehri M, Alshuwairikh S. The characteristics and distribution of dentist workforce in Saudi Arabia: A descriptive cross-sectional study. Saudi Pharm J 2017; 25(8): 1208-16. [http://dx.doi.org/10.1016/j.jsps.2017.09.005] [PMID: 29204070]

[10] Rose S. Medical student education in the time of Covid-19. JAMA 2020; 323(21): 2131-2.

[http://dx.doi.org/10.1001/jama.2020.5227] [PMID: 32232420]

[11] Alzahrani SB, Alrusayes AA, Aldossary MS. Impact of COVID-19 pandemic on dental education, research, and students. Int J Health Sci Res 2020; 10(6): 207-12.

[12] Al Rubaish A. A comparative appraisal of timings for program evaluation survey and related institutional results in Saudi Arabia: quality management in higher education. J Serv Sci Manag 2011; 4(2): 184-90.

[http://dx.doi.org/10.4236/jssm.2011.42022]

[13] Al Rubaish A. The usefulness of global student rating items under end program evaluation surveys in quality improvements: An institutional experience in higher education, Saudi Arabia. iBusiness2011; 3(4): 353-8.

[14] Abdelsalam M, Rodriguez TE, Brallier L. Student and faculty satisfaction with their dental curriculum in a dental college in Saudi Arabia. Int J Dent 2020; 2020: 6839717.

[http://dx.doi.org/10.1155/2020/6839717] [PMID: 32322273]

[15] George D, Mallery P. SPSS for windows step by step: A simple guide and reference 110 update. Boston: Allyn and Bacon 2003.

[16] Lavin A, Korte L, Davies T. Student gender and perceptions of 
teaching effectiveness. Res High Educ 2012; 18: 1-16.https://files.eric.ed.gov/fulltext/EJ1064676.pdf

[17] Jawaid M, Raheel S, Ahmed F, Aijaz H. Students' perception of educational environment at Public Sector Medical University of Pakistan. J Res Med Sci 2013; 18(5): 417-21.

[PMID: 24174949]

[18] Daniel D, Liben G, Adugna A. Assessment of students' satisfaction: a case study of Dire Dawa University, Ethiopia. J Educ Pract 2017; 8(4): 111-20.

[19] Binshehab SM, Ingle NA. Perception for online learning among undergraduate and postgraduate dental students during COVID-19 pandemic. Ann Med Health Sci Res 2021; 11(3): 1334-9.

[20] Aziz Ansari K, Farooqi F, Qadir Khan S, et al. Perception on online teaching and learning among health sciences students in higher education institutions during the COVID-19 lockdown-ways to improve teaching and learning in Saudi colleges and universities. F1000 Res 2021; 10: 177

[http://dx.doi.org/10.12688/f1000research.28178.1] [PMID: 33824717]

[21] Riedy M, Yu J, Zhou J. Effect of teaching method on students' perceptions of instructor attributes. Adv Busi Res 2012; 3(1): 141-6.

[22] Al-Jobair AM, AlSarheed MA. Saudi dental students' opinions on the qualities and attributes of an effective dental teacher. Adv Med Educ Pract 2016; 7: 533-9.

[http://dx.doi.org/10.2147/AMEP.S113212] [PMID: 27729821]

[23] European Society of Endodontology (ESO). Quality guidelines for endodontic treatment: Consensus report of the European Society of Endodontology. Int Endod J 2006; 39(12): 921-30.

[http://dx.doi.org/10.1111/j.1365-2591.2006.01180.x]

[PMID:
[24] Zimmerman BJ. Self-efficacy: An essential motive to learn. Contemp Educ Psychol 2000; 25(1): 82-91.

[http://dx.doi.org/10.1006/ceps.1999.1016] [PMID: 10620383]

[25] Baaij A, Özok AR, Væth M, Musaeus P, Kirkevang L-L. Self-efficacy of undergraduate dental students in Endodontics within Aarhus and Amsterdam. Int Endod J 2020; 53(2): 276-84. [http://dx.doi.org/10.1111/iej.13218] [PMID: 31519031]

[26] Akhlaghi N, Mirkazemi H, Jafarzade M, Akhlaghi N. Does learning style preferences influence academic performance among dental students in Isfahan, Iran? J Educ Eval Health Prof 2018; 15: 8. [http://dx.doi.org/10.3352/jeehp.2018.15.8] [PMID: 29575848]

[27] Tanveer M, Bhaumik A, Hassan S, Ul Haq I. Covid-19 pandemic, outbreak educational sector and students online learning in Saudi Arabia. J Entrep Educ 2020; 23(3): 1-14. Available from: https://www.abacademies.org/articles/Covid-19-pandemic-outbreak-ed ucational-sector-1528-2651-23-3-589.pdf

[28] Sabbagh HJ, Bakhaider HA, Abokhashabah HM, Bader MU. Students' perceptions of the educational environment at King Abdulaziz University Faculty of Dentistry (KAUFD): A cross sectional study. BMC Med Educ 2020; 20(241)

[http://dx.doi.org/10.1186/s12909-020-02165-7]

[29] Al-Samadani KH, Ahmad MS, Bhayat A, Bakeer HA, Elanbya M. Comparing male and female dental students' perceptions regarding their learning environment at a dental college in Northwest, Saudi Arabia. Eur J Gen Dent 2016; 5(2): 80-5.

[http://dx.doi.org/10.4103/2278-9626.179556]

[30] Al Kuwaiti A, Subbarayalu AV. Appraisal of students experience survey (SES) as a measure to manage the quality of higher education in the Kingdom of Saudi Arabia: an institutional study using six sigma model. Educ Stud 2015; 41(4): 430-3.

[http://dx.doi.org/10.1080/03055698.2015.1043977]

\section{(C) 2021 Ahmed Al Kuwaiti}

This is an open access article distributed under the terms of the Creative Commons Attribution 4.0 International Public License (CC-BY 4.0), a copy of which is available at: https://creativecommons.org/licenses/by/4.0/legalcode. This license permits unrestricted use, distribution, and reproduction in any medium, provided the original author and source are credited. 